\title{
Botany
}

\section{Variations in growth and architecture in the range limit of Salix humboldtiana, the native willow from South America}

\begin{tabular}{|c|c|}
\hline Journal: & Botany \\
\hline Manuscript ID & cjb-2021-0017.R1 \\
\hline Manuscript Type: & Article \\
\hline $\begin{array}{r}\text { Date Submitted by the } \\
\text { Author: }\end{array}$ & 01-Jun-2021 \\
\hline Complete List of Authors: & $\begin{array}{l}\text { Salgado, Mariana; Instituto de Investigaciones en Recursos Naturales, } \\
\text { Agroecología y Desarrollo Rural } \\
\text { Gallo, Leonardo; Instituto Nacional de Tecnología Agropecuaria } \\
\text { Torres, Cristian ; Universidad Nacional del Comahue- CONICET } \\
\text { Stecconi, Marina; Universidad Nacional del Comahue- CONICET } \\
\text { Puntieri, Javier; Instituto de Investigaciones en Recursos Naturales, } \\
\text { Agroecología y Desarrollo Rural }\end{array}$ \\
\hline Keyword: & $\begin{array}{l}\text { ANNUAL SHOOTS, STRESSFUL CONDITIONS, SALIX, PLANT } \\
\text { ARCHITECTURE, RANGE LIMIT }\end{array}$ \\
\hline $\begin{array}{r}\text { Is the invited manuscript for } \\
\text { consideration in a Special } \\
\text { Issue? : }\end{array}$ & Not applicable (regular submission) \\
\hline
\end{tabular}

\section{SCHOLARONE' \\ Manuscripts}




\section{Variations in growth and architecture in the range limit of Salix humboldtiana, the native willow from South America}

Salgado Mariana ${ }^{1 *}$, Gallo Leonardo Ariel ${ }^{2,4}$, Torres Cristian Daniel ${ }^{3,5}$, Stecconi Marina ${ }^{3,6}$ and Puntieri Javier Guido 1,7

${ }^{1}$ IRNAD, Instituto de Investigaciones en Recursos Naturales, Agroecología y Desarrollo Rural, Universidad Nacional de Río Negro- CONICET. 8400. Bariloche, Argentina.

${ }^{2}$ EEA INTA Bariloche. 8400. Bariloche, Argentina.

${ }^{3}$ INIBIOMA, Instituto de Investigaciones en Biodiversidad y Medio Ambiente, Universidad Nacional del Comahue- CONICET. 8400. Bariloche, Argentina.

${ }^{4}$ leosogalo@gmail.com

5torresc@comahue-conicet.gob.ar

${ }^{6}$ stecconim@comahue-conicet.gob.ar

7jgpuntieri@gmail.com

*Corresponding author: msalgado@unrn.edu.ar 


\begin{abstract}
The conditions faced by edge populations of a tree species may affect the architecture of individual trees. The latitudinally broad range of Salix humboldtiana encompasses tropical to cold-temperate climatic regions, with its southernmost population in central Patagonia. We expected S. humboldtiana trees from the southern-edge population to develop smaller shoots and a lower level of axis differentiation than trees of this species from a more northerly population, and expected edge trees to outperform non-edge trees when growing in common-garden at an intermediate latitude. For juvenile individuals of $S$. humboldtiana from edge and non-edge natural populations, trunk diameter, height, branching angle, and the length, number of nodes, diameter, leaf area and specific leaf area of main branch and trunk annual shoots were measured. The size and extension rates of shoots developed by trees of both origins in a common-garden were also evaluated. In natural populations, shoot leaf area and specific leaf area were higher for the edge population than for non-edge population. In common garden, shoot extension period and length were higher for non-edge plants than for edge plants. Growth-period differences between populations in the common garden may support the hypothesis of stress adaptation in the southernmost $S$. humboldtiana trees.
\end{abstract}

Key words: ANNUAL SHOOTS, RANGE LIMIT, STRESSFUL CONDITIONS, PLANT ARCHITECTURE, SALIX

Abbreviations used: Ch (Chubut river), Ne (Negro river), RER (relative extension rate), RNR (relative node-production rate) 


\section{Introduction}

The edges of a species' range may be determined by physical barriers to the dispersion of the species, or by unbearably stressful conditions, e.g. in terms of water availability, temperature or soil type (Monjeau et al. 1998). At a species' range edges, populations tend to be distant from one another; limited gene flow between them may generate high inter-population and low intrapopulation genetic diversities (Pastorino and Gallo 2009). Therefore, edge populations could contain exclusive genotypes (Vucetich and Waite 2003) and/or inheritable epigenetic changes (Broitman 2018), and open divergent speciation pathways (Templeton 1981). The responses of an edge population to particular stressful conditions may differentiate this population from others of the same species. In this sense, in a context of global change, there has been growing interest in edge populations, as they would be the most affected by climate shifts (Habibzadeh et al. 2021). The study of intraspecific variations associated with edge populations has been broadly approached from ecological (Rapoport and Monjeau 2001), genetic (Vucetich and Waite 2003) and physiological (Granda et al. 2017) perspectives.

We have no knowledge of studies concerned with the effect of range edges on intraspecific architectural variations, except for specific cases such as the krummholz form of plants developed at high-altitude edges (Ennos 1997; Stecconi et al. 2010). The architectural variations of plants related to their exposure to stressful conditions can be studied at different inter-related scales (Fig. 1). A low-scale approach may be focused on the relative development of the different axis types that make up plants. In tree species, the differentiation of the main vertical axis (trunk) from its major branches (main branches) has sometimes been evaluated in terms of morphological and/or physiological attributes (Puntieri et al. 2003; MacFarlane and Kane 2017). Among the variables considered in the evaluation of axis differentiation in trees are 
the angle of insertion and the size of main branches relative to the trunk (McQueen 2000; MacFarlane and Kane 2017), and the morphological and/or functional traits of these axes' structural units (Puntieri et al. 2003). Annual shoots ${ }^{1}$ are convenient structural units to focus on in the case of tree species from temperate climates, in which growth seasonality often results in visible limits between consecutive shoots (e.g. Stecconi et al. 2010). In these cases, primary growth dynamics ${ }^{2}$, shoot length, diameter and slenderness (length/diameter ratio) are related to exploratory (e.g. Gajardo-Caviedes et al. 2005), mechanical and water-conductivity capacities (e.g. Niklas 1995, 2007; Yoshimura 2011). The number of leaves and the leaf area per shoot relate not only to light interception but also to future plasticity, as leaf production is proportional to the number of axillary buds (Kleiman and Aarsen 2007). Specific leaf area (SLA= leaf area/leaf weight) is related to the extension rate of a shoot (Poorter and de Jong 1999; Gray et al. 2019) and may be an indicator of the degree of water stress to which a plant is subject (Marshall and Monserud 2003; Wellstein et al. 2017). Finally, the ratio between the number of leaves and the stem diameter may provide a proxy to a shoot's capacity to supply nutrients to its photosynthetic organs. These low-scale morphological and functional traits give information about the interaction between plants and their environment.

At the whole-plant scale, it is widely accepted that the architectural development of trees under non-limiting conditions implies, for the large majority of species, the production of an array of axis categories, each one with particular morphological and functional attributes (Hallé et al. 1978; Barthélémy \& Caraglio 2007). The degree of axis differentiation may vary due to evolutionary forces. For instance, certain selection pressures may have favored the evolution of "cage shape" and "pole shape" plants, respectively, as responses to herbivory (Charles-

\footnotetext{
${ }^{1}$ Set of growth units developed in one growing season (Barthélémy and Caraglio 2007).

${ }^{2}$ Characterization of primary growth patterns, such as extension rates and duration of growth (Sabatier and Barthélémy 1999).
} 
Dominique et al. 2017) and fire (Staver et al. 2012). Intraspecific variations in axis differentiation may also result from plastic responses under specific environmental conditions such as strong winds (Feldpausch et al. 2011), and water stress (Yang et al. 2016).

Tree species with a broad latitudinal range may exhibit remarkable morphological and architectural variability in relation to the responses to seasonal and climate changes through latitudinal gradients. These gradients could greatly affect shoot morphology and primary growth dynamics and directly impact on crown architecture. Salix humboldtiana Willd. is the only willow species native to South America; its natural range extends from Mexico to southern Argentina (Correa 1984), and encompasses tropical, subtropical, temperate and cold-temperate climates. At its southernmost range limit, in Argentinian Patagonia, this species inhabits mainly on the sandbanks of watercourses (San Martín and Véliz 2006), which are nowadays invaded by introduced Salix species. Unlike the latter, S. humboldtiana reproduces mainly by seeds and exhibits low natural capacity for clonal propagation, at least in this region (Thomas et al. 2012). Frost susceptibility has been proposed as the main limiting factor for the southern range of this species (Dickmann and Kuzovkina 2014). Among the variations observed in S. humboldtiana throughout its extensive range is the passage from evergreeness and continuous growth in warm areas (e.g. Costa do Catalão in Brazil 310' S 5954' W, Parolin et al. 2002) to deciduousness and rhythmic growth in temperate areas (e.g. Malleco in Chile $38^{\circ} 47^{\prime}$ S $72^{\circ} 56^{\prime}$ W, San Martín and Véliz 2006). In general, Patagonian populations of S. humboldtiana are small and disjunct, and consist of few aged individuals, and dense but short-living populations of seedlings and saplings, which would indicate limitations. The study of architectural variations and growth patterns of these populations may provide key information for unravelling what factors are 
related to the range limits of a species that, like $S$. humboldtiana, is capable of surviving in a wide range of climates.

In this work we studied axis differentiation and architectural traits related to shoots and crown structures of S. humboldtiana. We attempted to find out which architectural variations related to axis differentiation, shoot and crown structure could be expected towards this species' range limit. Under the assumption that the southernmost population of $S$. humboldtiana is subjected to stressful conditions, we would expect that, compared to a non-edge population (which is $500 \mathrm{~km}$ further north), the southernmost trees should have (1) a lower level of differentiation between the trunk and the main branches, and (2) trunk and main-branch shoots characterized by a short stem, small leaves, low branching angle, and a lower shoot length/diameter ratio. Additionally, since $S$. humboldtiana plants of the southernmost population would be more adapted to cold conditions than plants of a more northerly population, the latter would tend to grow less vigorously than the former when both were established at a site of intermediate latitude and low mean temperatures.

\section{Materials and Methods}

\section{Natural populations}

This study concerned two Patagonian populations of $S$. humboldtiana trees that exhibit the growth pattern typical of temperate zones. Both populations developed along the sandbanks of two Patagonian rivers: Chubut river (hereafter "Ch"), the southernmost location of this species, and Negro river (hereafter "Ne"), $500 \mathrm{~km}$ north of Ch. Nearby localities are Gualjaina

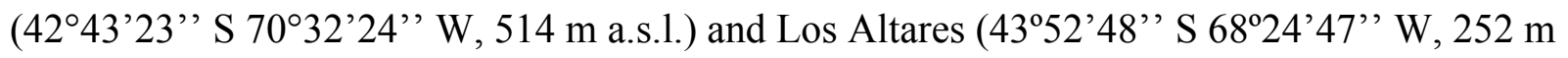
a.s.1.) for Ch, and General Roca (39 $1^{\prime} 45^{\prime}$ ' S 67 $35^{\prime} 23^{\prime}$ ' W, $241 \mathrm{~m}$ a.s.1.) for Ne. The native 
vegetations at the $\mathrm{Ch}$ and $\mathrm{Ne}$ sampling sites correspond, respectively, to steppe and monte ecoregions (Morello et al. 2012). The course of Ch crosses over fields dedicated to traditional extensive sheep and goat farming, and has been artificially modified only in a minor way. The course of $\mathrm{Ne}$ crosses a region of intensive fruit production activities (known as Alto Valle de Río Negro) and has been affected by ditches, canals and hydroelectric dams. The mean annual temperature at the $\mathrm{Ch}$ basin varies between $9.7^{\circ} \mathrm{C}$ near its origin and $13.5^{\circ} \mathrm{C}$ near its mouth to the sea. For Ne, mean temperatures at its origin and at its mouth vary between $14{ }^{\circ} \mathrm{C}$ and $14.2^{\circ} \mathrm{C}$, respectively (Morello et al. 2012). The maximum daylength is 15:28 hours at Ch and 14:55 hours at Ne (Global Monitoring Laboratory 2021).

\section{Measurements in wild populations}

In March 2019, 15 individuals of $S$. humboldtiana from Ch (height: 5-14 m, trunk diameter at base: $14-73 \mathrm{~cm}$ ) and 10 from Ne (height: $5-12 \mathrm{~m}$, trunk diameter: $12-40 \mathrm{~cm}$ ) were selected. The minimum distance between selected trees was $2 \mathrm{~m}$. From an external perspective, all trees were in good condition and did not have evident crown dieback. All of them were juvenile to juvenile-adult (with flowers) trees, i.e. they were in a pre-reproductive stage or some of them were reaching sexual maturity, producing few flowering axes. Two axis categories were selected for each tree: the trunk was the longest vertical axis of the plant and the main branch was the most vigorous (in terms of stem diameter) lateral axis derived from the trunk above breast height (Fig. 1). Basal trunk diameter (measured at ground level), total tree height and the angle formed between the trunk and the main branch were measured for each tree. The branching angle was calculated by averaging the angles formed between the main branch and the trunk at the proximal and distal ends of the branch (Fig. 1). Three branching-angle groups were 
established: $0^{\circ}-30^{\circ}$ (i.e. main branch codominant with the trunk), $31^{\circ}-60^{\circ}$ (i.e. main branch in a slanted position) and $61^{\circ}-90^{\circ}$ (i.e. main branch in a nearly horizontal position). Length, number of nodes, basal diameter, leaf area and SLA were recorded for the most recently extended annual shoot of the trunk and for that of the main branch. Leaf area per annual shoot was computed with the ImageJ program on scanned images of the leaves, and leaf dry weight per annual shoot was obtained after drying the leaves in an oven at $60^{\circ} \mathrm{C}$ to constant weight ( $\square 72$ hours) and weighing them with a precision scale (to the nearest $0.001 \mathrm{~g}$ ).

\section{Common garden experiment}

The material used for the common-garden experiment consisted in 15 individuals of $S$. humboldtiana, clonally obtained from 15 adult individuals of natural populations: seven individuals derived from trees of the Ne population and eight individuals derived from trees of the Ch population. For clonal reproduction, one main branch was harvested from each selected tree in winter 2013. In both populations, selected trees were more than $50 \mathrm{~m}$ apart from each other. The branches were kept in water until the beginning of spring (September), when 20-25 $\mathrm{cm}$ long cuttings were obtained, excluding the distal buds. The cuttings were established in an outdoor plantation placed in the ground $40 \mathrm{~cm}$ apart from each other, grouped by drainage basin, under full sun exposure and daily watering at EEA INTA Bariloche $\left(41^{\circ} 07^{\prime} 27^{\prime \prime} \mathrm{S} 71^{\circ} 14^{\prime} 53^{\prime}\right.$ ' W, $780 \mathrm{~m}$ a.s.1.), without supplemental fertilizer. The climographs (temperature and precipitation) corresponding to Gualjaina (near Ch), General Roca (near Ne) and Bariloche (common garden location) are shown in Fig. 2. In September 2018, prior to the start of the 2018-2019 growth season, when the trees were five years old (mean basal diameter $=49.5 \mathrm{~mm}$ ), five consecutive axillary buds formed close to the distal end of the trunk were marked. The apex of the trunk of 
most individuals had died during the preceding autumn-winter period; the length of the dead portion (extent of die-back) was measured for each plant. During the 2018-2019 growth season (September to May), the number of nodes and the length of the annual shoot derived from each of the five buds per plant were recorded every ten days to the nearest mm with a ruler. In May 2019, at the end of the growth season, the basal diameter of the shoot derived from each of the marked buds was measured to the nearest $0.1 \mathrm{~mm}$ with a digital caliper. The weekly relative extension rate (RER) of each shoot was calculated from each pair of successive length measurements using equation [1] (Torres et al. 2018):

[1] $\quad \operatorname{RER}_{1-2}=\frac{\log (L 2)-\log (L 1)}{t 2-t 1} \times 7$

where $L 2$ and $L 1$ are the lengths of the shoot at times $t 2$ and $t 1$ (in number of days counted from the first measure), respectively. The relative node-production rate (RNR) of each shoot was calculated as described for [1] but with number of nodes instead of length. In turn, the duration of the extension period of each shoot was recorded (the period with RER $>0$ ).

\section{Data analyses}

Trees growing at $\mathrm{Ch}$ and $\mathrm{Ne}$ were compared regarding each of the following shoot-level response variables: (a) length, (b) diameter, (c) number of nodes, (d) SLA, (e) length/diameter ratio, (f) number of nodes/diameter ratio, and (g) leaf area/diameter ratio. Since two shoots were measured for each tree, one trunk and one main-branch shoot, the applied model for each response variable considered axis category (trunk and main branch) and population ( $\mathrm{Ch}$ and $\mathrm{Ne}$ ) as fixed factors. Considering the dependence of the main-branch shoot and the trunk shoot within individuals, mixed effects models were initially tested, with "tree" as random factor. Nevertheless, non-significant improvement of models including the random factor was 
confirmed after Chi-Square likelihood-ratio tests, so fixed-effects linear models were applied; the significance of the effects of the fixed factors and their interactions were tested with ANOVAs. The interaction between both fixed factors was further excluded from models as they were not significant.

Variations in the ratio between the diameters of trunk and main-branch shoots $\left(\mathrm{d}_{\mathrm{Tr}} / \mathrm{d}_{\mathrm{Mb}}\right)$ were analyzed by means of a linear model including population and branching angle as fixed factors (interaction between both was also tested). As data did not comply with the homoscedasticity precondition, a model with non-homogenous variance was applied, by means of varIdent variance structure in the R software (R Development Core Team 2018).

For each plant in the common garden, the RER and the RNR were plotted over time. In order to evaluate the variability in the extension periods for the plants of each provenance, the standard errors of the times of extension initiation, extension end, maximum RER, and maximum RNR were computed. Variation between both provenances was evaluated for the following variables: (a) maximum RER, (b) mean RER, (c) maximum RNR, (d) duration of the extension period, and (e) length, (f) basal diameter, (g) number of nodes, (h) length/diameter ratio, (i) number of nodes/diameter ratio and (j) length of the dead apex portion of measured shoots. Due to the fact that five shoots per plant were measured, mixed linear models were applied, considering provenance as fixed factor and individual as random factor, with the lme function in the nlme package in R (R Development Core Team 2018). For each model, the significance of the variation between provenances was tested by ANOVA type III Kenward-Roger.

The relationship between length and basal diameter was evaluated both for the distal annual shoots and for whole plants of natural populations and in the common garden. The Michaelis-Menten nonlinear model, widely used in enzymatic kinetics, was fitted to each 
population to describe length/diameter relationships. This model takes the form described in equation [2] (Michaelis and Menten 1913):

[2] $\quad \log ($ length $)=a+\frac{b * \log (\mathrm{d})}{c+\log (\mathrm{d})}$

where $\mathrm{d}$ is the shoot's basal diameter, and $a, b$ and $c$ are the parameters of the model. The intercept, $a$, is the length at zero diameter, $b$ is the asymptotic length value, and $c$ is the diameter at half the maximum length. Differences between populations regarding these parameters were assessed through the overlapping of their $95 \%$ confidence intervals.

\section{Results}

Comparisons between $\mathrm{S}$. humboldtiana trees in wild populations

Shoot length and number of nodes were similar for trees of both populations $(\mathrm{F}=0.6 \mathrm{p}=$ $0.4, F=0.5 p=0.5$, respectively) and derived from both axis categories $(F=1.3 p=0.2, F=2.4$ $\mathrm{p}=0.1$, respectively). Shoot diameter and leaf area were higher in trunk shoots than in mainbranch shoots $(F=8.8 p=0.005, F=4.2 p=0.04$, respectively), whereas the converse was found for the length/diameter $(F=5.1 \mathrm{p}=0.03)$ and number of nodes/diameter ratios $(\mathrm{F}=8.7 \mathrm{p}$ $=0.005)$. Shoot diameter and the length/diameter ratio did not differ between populations $(\mathrm{F}=$ $3.8 \mathrm{p}=0.6, \mathrm{~F}=2.1 \mathrm{p}=0.2$, respectively), and SLA and the leaf area/diameter ratio did not differ between axis categories $(\mathrm{F}=3.0 \mathrm{p}=0.09, \mathrm{~F}=0.09 \mathrm{p}=0.8$, respectively). Shoot leaf area, SLA and the leaf area/diameter ratio were higher for $\mathrm{Ch}$ than for Ne plants $(\mathrm{F}=5.8 \mathrm{p}=0.02, \mathrm{~F}=19.3$ $\mathrm{p}<0.001, \mathrm{~F}=4.5 \mathrm{p}=0.04$, respectively), whereas the number of nodes/diameter ratio was higher for the latter population $(\mathrm{F}=11.3 \mathrm{p}=0.002$; Table 1$)$.

In both populations, the angle between the trunk and the main branch was predominantly lower than $30^{\circ}$, i.e. the main branch tended to be codominant with the trunk (Fig. 3). Wide 
branching angles $\left(61^{\circ}-90^{\circ}\right)$ were more frequently observed in Ch plants. The $\mathrm{d}_{\mathrm{Tr}} / \mathrm{d}_{\mathrm{Mb}}$ ratio tended to increase together with the branching angle in Ch plants but not in Ne plants; this trend was confirmed by the significant interaction between branching angle and population on this ratio (F $=4.6, \mathrm{p}=0.01)$.

\section{Comparisons between populations in common garden}

No differences between $\mathrm{Ch}$ and $\mathrm{Ne}$ trees were found regarding maximum $\mathrm{RER}(\mathrm{F}=0.8, \mathrm{p}$ $=0.4$; Fig. 4A), mean RER $(\mathrm{F}=0.2, \mathrm{p}=0.64)$ and maximum $\mathrm{RNR}(\mathrm{F}=0.8, \mathrm{p}=0.4$; Fig. 4B). The time of occurrence of the maximum RER was more variable in Ch plants $(\mathrm{SE}=5.2)$ than in Ne plants $(\mathrm{SE}=1.8)$, but for both populations the maximum RER was recorded between 17 December 2018 and 7 January 2019.

The trunk shoots produced by Ne plants were, on average, longer $(F=10.4, p=0.008$; Table 1) and thicker $(\mathrm{F}=10.8, \mathrm{p}=0.009$; Table 1$)$ than those produced by Ch plants, whereas the number of nodes per shoot was similar for both populations $(F=4.4, p=0.059$; Table 1$)$. The length/diameter ratio of annual shoots was significantly higher in Ne than in Ch plants $(\mathrm{F}=$ $6.4, \mathrm{p}=0.032$; Table 1$)$. The number of nodes/diameter ratio was not affected by population $(\mathrm{F}=$ $4.4, p=0.065$; Table 1). Shoots of Ne plants extended for a longer period than those of Ch plants $(97.6 \pm 6.0$ days and 70.2 \pm 7.0 days, respectively; $F=7.1, p=0.02)$. Both populations were similar regarding the variabilities in the times of shoot-extension initiation $\left(\mathrm{SE}_{\mathrm{Ch}}=1.8\right.$ and $\mathrm{SE}_{\mathrm{Ne}}$ $=1.3)$ and end $\left(\mathrm{SE}_{\mathrm{Ch}}=3.6 ; \mathrm{SE}_{\mathrm{Ne}}=3.6\right)$. The dead distal portion of the trunk measured at the beginning of the growth season was longer for $\mathrm{Ne}(6.5 \pm 0.7 \mathrm{~cm})$ than for $\mathrm{Ch}$ plants $(3.9 \pm 0.4 \mathrm{~cm}$; $\mathrm{F}=12.1, \mathrm{p}<0.001)$ 


\section{Length/diameter relationships for wild and common-garden trees}

The relationship between length and diameter (both log-transformed) for shoots and whole plants was closely fitted by the Michaelis-Menten model (Fig. 5). All three parameters of the models were similar between populations (Supplementary data Table S1).

\section{Discussion}

Annual-shoot structure in edge and non-edge S. humboldtiana trees

The objective of this study was to compare S. humboldtiana trees from the southernmost population (Chubut river; $\mathrm{Ch}$ ) with those from a non-edge population (Negro river; $\mathrm{Ne}$ ) in terms of annual-shoot growth and structure, and axis differentiation (trunk and main branch). Variation between morphological traits of trunk shoots and main-branch shoots were similar in both populations. Whereas the trunk develops thicker shoots with higher photosynthetic area, main branches develop shoots with higher length/diameter and number of nodes/diameter ratios. These morphological differences between trunk and main-branch shoots have been observed for other willows (e.g. Remphrey and Pearn 2006) and could impact on the whole tree architecture. Differences between $\mathrm{Ch}$ and Ne trees regarding leaf area, SLA and leaf area/diameter ratio $(\mathrm{Ch}>\mathrm{Ne})$ at the annual-shoot level were opposite to our prediction, as low leaf areas have often been associated with cold-stress responses in some species' range edges (Gratani 2014). This apparent inconsistency may be explained by differences between populations in terms of water availability, considering that $\mathrm{Ne}$ plants were farther away from the river than $\mathrm{Ch}$ plants (personal observation). In trees of the latter population, the development of fewer leaves per unit of shoot diameter in natural conditions could be interpreted as a higher investment of resources to support, transport and reserve tissues than to photosynthetic and gas-exchange tissues (Mesquita 
Oliveira et al. 2019). However, the shoots from Ch had, as compared to those of Ne, fewer but larger leaves in relation to shoot diameter. In other words, by increasing the expansion of each leaf, a growing shoot may increase its photosynthetic surface despite having a low number of leaves.

The relationship between the branching angle and the $\mathrm{d}_{\mathrm{Tr}} / \mathrm{d}_{\mathrm{Mb}}$ ratio differed between both wild populations: branches at a nearly horizontal orientation were thinner in relation to the trunk in Ch than in Ne plants. This result would imply a lower relative resource allocation to branches with a horizontal orientation and, therefore, the development of trees with narrower crowns in $\mathrm{Ch}$ than in Ne. Thus, contrary to our expectation, a higher level of differentiation between trunk and main branches could be inferred for Ch than for Ne S. humboldtiana trees, suggesting that environmental conditions at the edge of the range of this species would not promote the development of trees with less axis differentiation.

Under common-garden conditions, $\mathrm{Ch}$ trees developed shorter and thinner shoots than $\mathrm{Ne}$ trees. Since plants from both populations reached similar rates of extension and node-production, their differences in shoot size may be attributed to growth duration. It has been shown for Populus that inter-population differences in growth depend on the photoperiod at different latitudes (Savage and Cavender-Bares 2013; Liu and El-Kassaby 2019). Sensing photoperiodic cues is achievable by Populus due to the presence of a shoot apical meristem, responsible for the bud dormancy establishment (Singh et al. 2017). However, as Salix species do not form an apical bud, other environmental cues, such as temperature, which are perceived by the whole plant (Fadón et al. 2020), become important for bud set. On these grounds, the shorter growth period of Ch shoots could be a consequence of the adaptation of this population to cold spells during the summer, which are more frequent in southern than northern areas of Patagonia (de Fina 1972). 
The lower extent of shoot die-back recorded for Ch plants than for Ne plants developed in the common garden with relatively cold conditions endorses this view. This study supports the idea that some aspects of the primary-growth dynamics have greater genetic determination than others or, at least, that some genetic signals of the place of origin of a plant may be expressed at early ontogenetic stages (Gallo et al. 2020).

For common-garden plants of both populations, the maximum RER was similar and occurred between mid-December and early January (i.e. early summer), that is, later than in other native Patagonian woody species studied so far (with maximum RER in early-mid spring; e.g. Stecconi et al. 2017; Puntieri et al. 2018). This contrast may be due to the low number of leaf primordia present in the winter buds (i.e. preformation) of $S$. humboldtiana compared to other broadleaf Patagonian species (J. Puntieri, personal observation). Preliminary data indicate that shoot size variability in this species may be mostly conditioned by the extent of neoformation, i.e. the simultaneous differentiation and extension of organs during the growth season, as found for Populus trichocarpa (Critchfield 1960) and other tree species (Wu and Hinckley 2001). Neoformation could then be the cause of high summer growth rates in common-garden $S$. humboldtiana plants (Fig. 4); this process would have lasted longer in Ne plants than in Ch plants, but the former were more affected by shoot die-backs. This suggests that $\mathrm{Ch}$ plants have a different perception of environmental cues to stop seasonal shoot extension.

Due to the dispersal mode of $S$. humboldtiana and its riparian habitat, gene flow between both populations studied here would be highly unlikely (Hernández-Leal et al. 2019). This makes us presume some degree of genetic differentiation between these populations, which may explain the more conservative growth dynamics exhibited by those plants derived from the southernmost population of this species; these plants may seem more suitable to establish at sites where late- 
summer conditions are more stressful. Based on our results, and considering that $S$.

humboldtiana exhibits continuous growth in tropical regions (Parolin et al. 2002), it could be expected that its growth period would increase as latitude decreases. The higher susceptibility to cold spells of plants of Ne population suggests that this could be a strong selective force in high latitudes. The high level of phenotypic plasticity that characterizes many willow trees (Dickmann and Kuzovkina 2014) may have increased, in the present case, between-population similarities regarding other traits expressed in the common garden, such as shoot extension initiation. Under this assumption, S. humboldtiana plants could be transferred between areas of Patagonia (e.g. for wood production or vegetation restoration) with good prospects of success. On the other hand, the selection of S. humboldtiana plants with domestication purposes based on phenotypic characteristics could be ineffective given the high genotype $\times$ environment interaction.

\section{Length/diameter relationships}

The shoot length/diameter ratio has been investigated for trees at different scales and with different goals, as this ratio is related to several functions, such as the capacity to extend the tree crown in height or sideways, the stability of trees in relation to static and dynamic loads and the storage of non-structural carbohydrates (e.g. McMahon and Kronauer 1976; Niklas 1995; MacFarlane and Kane 2017 and references therein). Published data on S. humboldtiana from northeast Argentina (SINAVIMO 2016), Chile (Pinilla et al. 2015), México (Hernández-Leal et al. 2019) and Colombia (Giraldo et al. 2009), reported taller tree heights relative to trunk diameter than in the present case. Trees subject to strong winds generally have a low length/diameter ratio (Woodward 1989), and Patagonia is likely to be the region with the strongest winds within the range of S. humboldtiana (up to $12 \mathrm{~m} / \mathrm{s}$ at $80 \mathrm{~m}$ altitude; AWS 
Truepower 2015). Wind force could be proposed as a relevant factor affecting the height/diameter relationship in this species (Feldpausch et al. 2011). The fact that $S$. humboldtiana usually regenerates in patches of high seedling density may be related to the beneficial effect each seedling may have on its neighbors through mutual support.

With regard to the length/diameter ratio of annual shoots, we found lower values for $S$. humboldtiana trees in natural populations than for trees grown in a common garden, independently of the population. This difference may be related to the stronger winds that affected wild-population trees as compared to those in the common garden; the increment in shoot diameter has been found to be one of the responses of trees to increasing wind loads $(\mathrm{Wu}$ et al. 2016). Better conditions for length growth in the common garden may also have contributed to the higher differences in shoot length/diameter ratio between common-garden and wild-population trees (see Heuret et al. 2006). The higher length/diameter ratios found for mainbranch than for trunk shoots at both river banks supports the idea that wind forces - to which trunks are more exposed than main branches - are involved in defining shoot structure in this species.

\section{Conclusions}

Despite the rather small sample sizes, significant differences between S. humboldtiana populations were found: e.g. higher number of nodes/diameter ratio for the non-edge population $(\mathrm{Ne})$ and a higher photosynthetic area for the edge population $(\mathrm{Ch})$. At the axis level, Ch showed a higher differentiation between the trunk and the main branch, which led to narrower crowns in Ch than in Ne. When growing in a common garden at an intermediate location, trees from the edge population developed, due to the shorter extension period, shorter shoots than those from a 
more northerly Patagonian population; the latter population showed signs of being less coldhardy than the edge population. Considering that the range of $S$. humboldtiana is mostly tropical/subtropical, it may be proposed that all Patagonian populations of $S$. humboldtiana could be under range-edge effects, suffering limitations to vegetative growth and population expansion.

\section{Acknowledgements}

The authors thank José Pablo Paniceres, Leonardo Salgado, Maya Svriz and Mariana Agüero for their assistance in plant measurements. This work was supported by INTA and CONICET.

\section{References}

AWS True Power. 2015. Wind resource of Argentina. In https://aws-dewi.ul.com/assets/WindResource-Map-Argentina-11x17.pdf

Barthélémy, D., and Caraglio, Y. 2007. Plant architecture: a dynamic, multilevel and comprehensive approach to plant form, structure and ontogeny. Ann. Bot. 99(3): $375-407$.

Broitman, B.R., Aguilera, M.A., Lagos, N.A., and Lardies, M.A. 2018. Phenotypic plasticity at the edge: constrasting population-level responses at the overlap of the leading and rear edges of the geographical distribution of two Scurria limpets. J. Biog. 45(10):1-12.

Charles-Dominique, T., Barczi, J.F., Le Roux, E., and Chamaillé-Jammes, S. 2017. The architectural design of trees protects them against large herbivores. Funct. Ecol. 31(9): 1-8 doi: $10.1111 / 1365-2435.12876$

Correa, M.N. 1984. Flora Patagónica. Parte IV a. Dicotiledóneas dialipétalas (Salicaceae a Cruciferae). Colección Científica del INTA. Buenos Aires. 
Critchfield, W.B. 1960. Leaf dimorphism in Populus trichocarpa. Am. J. Bot. 47: 699-711.

De Fina, A.L. 1972. El clima de la región de los bosques andino-patagónicos argentinos. In La región de los bosques andino-patagónicos. Edited by Dimitri, M. Colección Científica del INTA. Buenos Aires, 10: 35-50.

Dickmann, D.I., and Kuzovkina, J. 2014. Poplars and willows of the world, with emphasis on sylviculturally important species. In Poplars and willows: trees for society and the environment. Edited by Isebrands, J.G., and Richardson, J. Rome, Italy, CAB International and FAO: 634.

Ennos, A.R. 1997. Wind as an ecological factor. Trends Ecol. Evol. 12: 108-111.

Fadón, E., Fernández, E., Behn, H., and Luedeling, E. 2020. A conceptual framework for winter dormancy in deciduous trees. Agronomy 10(241): 1-20.

Feldpausch, T.R., Banin, L., Phillips, O.L., Baker, T.R., Lewis, S.L., Quesada, C.A., et al. 2011. Height-diameter allometry of tropical forest trees. Biogeosciences 8:1081-1106.

Gajardo-Caviedes, P.A., Espinosa, M.A., González, U.T., and Ríos, D.G. 2005. The influence of thinning and tree size on the sapwood area/leaf area ratio in coigue. Can. J. For. Res. 35:1679-1685.

Gallo, L., Amico, I., Bozzi, J., Cedres, N., Cerrillo, T., Datri, L., et al. 2020. Salix humboldtiana, the ancient and unique native willow. In: Low Intensity Breeding of Native Forest Trees in Argentina, Genetic bases for their domestication and conservation. Pastorino, M., and Marchelli, P. (Eds). Springer. 334 pp.

Giraldo, L.A., Ríos, H.F., and Polanco, M.F. 2009. Efecto de dos enraizadores en tres especies forestales promisorias para la recuperación de suelos. Rev. Invest. Agr. Amb. 1: 41-47. 
Global Monitoring Laboratory. 2021. NOAA Solar Calculator, data available in http:/gml.noaa.gov/grad/solcalc/

Granda, E., Alla, A.Q., Laskurain, N.A., Loidi, J., Sánchez-Lorenzo, A., and Camarero, J.J. 2017. Coexisting oak species, including rear-edge populations, buffer climate stress through xylem adjustments. Tree Physiol. 38(2): 159-172. doi:10.1093/treephys/tpx157

Gratani, L. 2014. Plant phenotypic plasticity in response to environmental factors. Adv. Bot. 2014: 1-17. doi:10.1155/2014/208747

Gray, E.F., Wright, I.J., Falster, D.S., Eller, A.S.D., Lehmann, C.E.R., Bradford, M.G., and Cernusak, L.A. 2019. Leaf:wood allometry and functional traits together explain substantial growth rate variation in rainforest trees. AoB Plants 11(3): 1-11. doi:10.1093/aobpla/plz024

Habibzadeh, N., Ghoddousi, A., Bleyhl, B., and Kuemmerle, T. 2021. Rear-edge populations are important for understanding climate change risk and adaptation potential of threatened species. Conserv. Sci. Pract. 3(5): 1-13.

Hallé, F. 1978. Architectural variation at specific level of tropical trees. In Tropical trees as living systems. Edited by Tomlinson, P.B., Zimmermann, M.H. Cambridge: Cambridge University Press, pp 209-221.

Hernández-Leal, M.S., Suárez-Atilano, M., Piñero, D., and González-Rodríguez, A. 2019. Regional patterns of genetic structure and environmental differentiation in willow populations (Salix humboldtiana Willd.) from Central Mexico. Ecol. Evol. 9: 9564-9579.

Heuret, P., Meredieu, C., Coudurier, T., Courdier, F., and Barthélémy, D. 2006. Ontogenetic trends in the morphological features of main stem annual shoots of Pinus pinaster Ait. (Pinaceae). Am. J. Bot. 93: 1577-1587. 
Kleiman, D., and Aarsen, L.W. 2007. The leaf size/number trade-off in trees. J. Ecol. 95: 376-382.

Liu, Y., and El-Kassaby, Y. 2019. Phenotypic plasticity of natural Populus trichocarpa populations in response to temporally environmental change in a common garden. BMC Evol. Biol. 19(231): 1-15.

MacFarlane, D.W., and Kane, B. 2017. Neighbor effects on tree architecture: functional tradeoffs balancing crown competitiveness with wind resistance. Funct. Ecol. 31:1624-1636.

Marshall, J.D., and Monserud, R.A. 2003. Foliage height influences specific leaf area of three conifer species. Can. J. For. Res. 33(1): 164-170.

McMahon, T.A., and Kronauer, R.E. 1976. Tree structures: deducting the principle of mechanical design. J. Theor. Biol. 59: 443-466.

McQueen, D.R. 2000. Divaricating shrubs in Patagonia and New Zealand. New Zeal. J. Ecol. 24(1): 69-80.

Mesquita Oliveira, F.F., Bizerra de Morais, M., de Souza Silva, M.E., Fernandes Saraiva, Y.K., de Mesquita Arruda, M.V., Costa e Silva, J.N., and Cavalcanti de Albuquerque, C. 2019. Ecophysiological response of Lippia gracilis (Verbenaceae) to duration of salt stress. Ecotox. Environ. Safe. 178: 202-210.

Michaelis, L., and Menten, M.L. 1913. Die Kinetik der Invertinwirkung. Biochem. Z. 49: $333-369$.

Monjeau, J.A., Birney, E.C., Ghermandi, L., Sikes, R.S., Margutti, L., and Phillips, C.J. 1998. Plants, small mammals, and the hierarchical landscape of Patagonia. Landscape Ecol. 13: $285-306$. 
Morello, J., Matteucci, S., Rodríguez, A., Silva, M.E. 2012. Ecorregiones y complejos ecosistémicos argentinos. Orientación Gráfica Editora, Buenos Aires, Argentina. 752 pp.

Niklas, K.J. 1995. Size-dependent allometry of tree height, diameter and trunk-taper. Ann Bot. 75(3): 217-227.

Niklas, K.J. 2007. Maximum plant height and the biophysical factors that limit it. Tree Physiol. 27(3): 433-440.

Parolin, P., Oliveira, A.C., Piedade, M.T.F., Wittmann, F., and Junk, W.J. 2002. Pioneer trees in Amazonian floodplains: three key species form monospecific stands in different habitats. Folia Geobot. 37: 225-238.

Pastorino, M.J., and Gallo, L.A. 2009. Preliminary operational genetic management units of a highly fragmented forest tree species of southern South America. For. Ecol. Manag. 257: $2350-2358$.

Pinilla, J.C., Chung, P., and Navarrete, M. 2015. El sauce chile (Salix humboldtiana) en la región del Bio-Bio y su uso potencial en bosques plantados. Informe técnico No202. Instituto Forestal, Chile. 43 pp.

Poorter, H., and de Jong, R. 1999. A comparison of specific leaf area, chemical composition and leaf construction costs of field plants from 15 habitats differing in productivity. New Phytol. 143(1): 163-176.

Puntieri, J.G., Souza, M.S., Brion, C., Mazzini, C., and Barthélémy, D. 2003. Axis differentiation in two South American Nothofagus species (Nothofagaceae). Ann. Bot. 92: 589-599.

Puntieri, J.G., Torres, C., Magnin, A., Stecconi, M., and Grosfeld, J. 2018. Structural differentiation among annual shoots as related to growth dynamics in Luma apiculata trees (Myrtaceae). Flora 249: 86-96. 
R Development Core Team. 2018. R: A language and environment for statistical computing. R Foundation for Statistical Computing, Vienna, Austria.

Rapoport, E.H., and Monjeau, J.A. 2001. Areografía. In Introducción a la biogeografía en Latinoamérica: teorías, conceptos, métodos y aplicaciones. Edited by Llorente Bousquets, J., and Morrone, J.J. pp 23-30.

Remphrey, W.R., and Pearn, L.P. 2006. Crown architecture development in Salix 'Prairie Cascade', a pendulous willow. Can. J. Bot. 84: 1531-1541.

Sabastier, S., and Barthélémy, D. 1999. Growth dynamics and morphology of annual shoots, according to their architectural position, in young Cedrus atlantica (Endl.) Manetti ex Carrière (Pinaceae). Ann. Bot 84: 387-392.

San Martín, J., and Véliz, V. 2006. Salix humboldtiana Willd. Sauce chileno. Familia Salicaceae. In Las especies arbóreas de los bosques templados de Chile y Argentina. Autoecología. Edited by Donoso Zegers, C. Marisa Cuneo Ediciones. Valdivia, Chile. pp 556-560. Savage, J.A., and Cavender-Bares, J. 2013. Phenological cues drive an apparent trade-off between freezing tolerance and growth in the family Salicaceae. Ecology 94(8): $1708-1717$.

SINAVIMO (Sistema Nacional Argentino de Vigilancia y Monitoreo de Plagas). 2016. Salix humboldtiana. Available from: https://www.sinavimo.gov.ar/cultivo/salix-humboldtiana Singh, R.K., Svystum, T., AlDahmash, B., Jönsson, A.M., Bhalerao, R.P. 2017. Photoperiodand temperature-mediated control of phenology in trees - a molecular perspective. New Phytol. 213: 511-524. 
Staver, C., Bond, W.J., Cramer, M.D., and Wakeling, J.L. 2012. Top-down determinants of niche structure and adaptation among African Acacias. Ecol. Lett. 15: 673-679. doi: $10.1111 / \mathrm{j} .1461-0248.2012 .01784 . \mathrm{x}$

Stecconi, M., Puntieri, J., and Barthélémy, D. 2010. An architectural approach of growth forms of Nothofagus pumilio (Nothofagaceae) along an altitudinal gradient. Botany $\mathbf{8 8}(8)$ : 699-709.

Stecconi, M., Quevedo, L., Magnin, A., Torres, C., Lediuk, K., Svriz, M., et al. 2017. Desarrollo de especies leñosas nativas y exóticas en cipresales patagónicos. Bol. Soc. Arg. Bot. 52(2): 507-522.

Templeton, A.R. 1981. Mechanism of speciation- a population genetic approach. Ann. Rev. Ecol. Evol. S. 12: 23-48.

Thomas, L.K., Tölle, L., Ziegenhagen, B., and Leyer, I. 2012. Are vegetative reproduction capacities the cause of widespread invasion of Eurasian Salicaceae in Patagonian river landscapes? PLOS one 7(12): e50652.

Torres, C.D., Magnin, A., Varela, S.A., Stecconi, M., Grosfeld, J.E., Puntieri, J.G. 2018. Morpho-physiological responses of Nothofagus obliqua to light intensity and water status, with focus on primary growth dynamics. Trees 32(5): 1301-1314.

Vucetich, J.A., and Waite, T.A. 2003. Spatial patterns of demography and genetic processes across the species' range: Null hypotheses for landscape conservation genetics. Conserv. Genet. 4: 639-645.

Wellstein, C., Poschlod, P., Gohlke, A., Chelli, S., Campetella, G., Rosbakh, S., et al. 2017. Effects of extreme drought on specific leaf area of grassland species: a meta-analysis of 
experimental studies in temperate and sub-Mediterranean systems. Glob. Change Biol. 23(6): 2473-2481.

Woodward, F.I. 1989. The impact of environmental stresses on ecosystems. In Plants under stress. Edited by Jones, H.G., Flowers, T.J., and Jones, M.B. Cambridge University Press, Cambrigde, UK. pp 11-29.

Wu, R., and Hinckley, T.M. 2001. Phenotypic plasticity of sylleptic branching: genetic design of tree architecture. Crit. Rev. Plant Sci. 20(5): 467-485.

Wu, T., Zhang, P., Zhang, L., Wang, G.G., and Yu, M. 2016. Morphological response of eight Quercus species to simulated wind load. PLoS one 11(9):1-14.

Yang, W., Pallas, B., Durand, J.-P., Martinez, S., Han, M. and Costes, E. 2016. The impact of long-term water stress on tree architecture and production is related to changes in transitions between vegetative and reproductive growth in the 'Granny Smith' apple cultivar. Tree Physiol. 36: 1369-1381.

Yoshimura, K. 2011. Hydraulic function contributes to the variation in shoot morphology whithin the crown in Quercus crispula. Tree Physiol. 31: 774-781 


\section{Figure captions:}

Figure 1. Diagrammatic representation of a Salix humboldtiana tree and main variables measured; at the axis level, the branching angle of the main branch, and at the annual-shoot level, the number of nodes, the length and the basal diameter.

Figure 2. Climographs for localities close to the $S$. humboldtiana populations at Chubut river (Gualjaina; 42 43'27'' S 70³2'22', W) and at Negro river (General Roca; 3902'01'' S $67^{\circ} 35^{\prime} 19^{\prime \prime} \mathrm{W}$ ) populations, and for the location of the common garden (Bariloche; $41^{\circ} 07^{\prime} 27^{\prime}$ ' $\mathrm{S}$ $\left.71^{\circ} 15^{\prime} 53^{\prime}, \mathrm{W}\right)$. Each climograph includes altitude, mean annual temperature (MAT) and annual rainfall (AR). Data from http://en.climate-data.org

Figure 3. Relative frequencies of branching-angle categories at Chubut river and Negro river populations.

Figure 4. (A) Relative extension rate (RER; cm/day) as a function of time (solid lines) and mean daily temperature $\left({ }^{\circ} \mathrm{C}\right.$; dotted line). (B) Relative node-production rate (RNR; nodes/day) as a function of time (solid lines) and mean daily temperature $\left({ }^{\circ} \mathrm{C}\right.$; dotted line). Error bars: $\pm 1 \mathrm{SE}$. Figure 5. Relationship between stem length and diameter (log-log scale) at annual shoot (circles) and whole plant (squares) levels, for wild-population (empty symbols) and common-garden trees (solid symbols), and for two populations (Chubut river and Negro river). The gray area represents the $95 \%$ confidence interval for the fitted line (inset equation). 
Table 1. Mean ( \pm SE) values for descriptive variables measured on trunk and main-branch shoots of Salix humboldtiana trees developed on two wild populations (Chubut river,

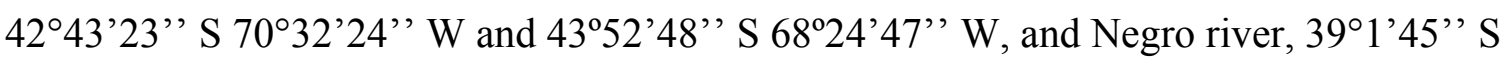
$67^{\circ} 35^{\prime} 23^{\prime \prime} \mathrm{W}$ ), and for the same variables of the trunk of plants grown in a common garden

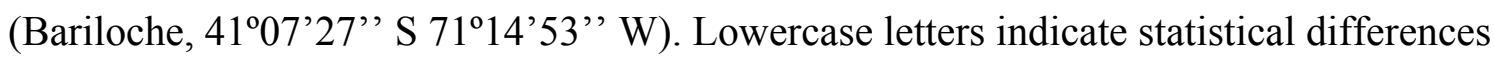
$(\mathrm{p}<0.05)$ among wild-population plants, and capital letters indicate statistical differences between common-garden plants of different population.

\begin{tabular}{|c|c|c|c|c|c|c|}
\hline & \multicolumn{4}{|c|}{ Wild population $^{1}$} & \multicolumn{2}{|l|}{ Common garden $^{2}$} \\
\hline & \multicolumn{2}{|c|}{ Chubut river $(\mathrm{n}=15)$} & \multicolumn{2}{|c|}{ Negro river $(\mathrm{n}=10)$} & \multirow{2}{*}{$\begin{array}{l}\text { Chubut river }(\mathrm{n}=8) \\
\text { Trunk }\end{array}$} & \multirow{2}{*}{$\begin{array}{l}\text { Negro river ( } \mathrm{n}= \\
7) \\
\text { Trunk }\end{array}$} \\
\hline & Trunk & Main branch & Trunk & Main branch & & \\
\hline \multirow[t]{2}{*}{ Length (cm) } & $29.7( \pm 4.2)$ & $21.6( \pm 2.0)$ & $22.5( \pm 3.6)$ & $23.1( \pm 5.0)$ & $16.1( \pm 2.1)$ & $33.0( \pm 2.4)$ \\
\hline & $\mathbf{a}$ & $\mathbf{a}$ & $\mathbf{a}$ & $\mathbf{a}$ & B & $\mathbf{A}$ \\
\hline \multirow[t]{2}{*}{ Diameter (mm) } & $4.5( \pm 0.5)$ & $2.9( \pm 0.2)$ & $3.3( \pm 0.5)$ & $2.6( \pm 0.3)$ & $2.3( \pm 0.2)$ & $3.2( \pm 0.2)$ \\
\hline & $\mathbf{a}$ & $\mathbf{b}$ & a & $\mathbf{b}$ & B & $\mathbf{A}$ \\
\hline \multirow[t]{2}{*}{ Number of nodes } & $43.1( \pm 3.1)$ & $37.0( \pm 2.1)$ & $39.2( \pm 2.6)$ & $36.5( \pm 4.1)$ & $30.8( \pm 2.7)$ & $37.8( \pm 1.7)$ \\
\hline & $\mathbf{a}$ & $\mathbf{a}$ & $\mathbf{a}$ & $\mathbf{a}$ & B & $\mathbf{A}$ \\
\hline \multirow[t]{2}{*}{ Leaf area $\left(\mathrm{cm}^{2}\right)$} & $143.5( \pm 19.0)$ & $100.7( \pm 10.2)$ & $93.4( \pm 14.9)$ & $75.8( \pm 16.3)$ & & \\
\hline & $\mathbf{a}$ & $\mathbf{b}$ & c & d & & \\
\hline Specific leaf area & $93.2( \pm 4.2)$ & $101.4( \pm 7.8)$ & $67.8( \pm 1.6)$ & $78.7( \pm 4.6)$ & & \\
\hline$\left(\mathrm{cm}^{2} / \mathrm{g}\right)$ & $\mathbf{b}$ & $\mathbf{a}$ & d & c & & \\
\hline \multirow[t]{2}{*}{ Length/diameter } & $6.4( \pm 0.3)$ & $7.3( \pm 0.4)$ & $6.9( \pm 0.4)$ & $8.4( \pm 0.9)$ & $8.3( \pm 0.6)$ & $11.0( \pm 0.4)$ \\
\hline & $\mathbf{b}$ & $\mathbf{a}$ & $\mathbf{b}$ & $\mathbf{a}$ & B & $\mathbf{A}$ \\
\hline \multirow[t]{2}{*}{ Nodes/diameter } & $10.2( \pm 0.6)$ & $12.8( \pm 0.5)$ & $13.2( \pm 1.0)$ & $14.7( \pm 1.0)$ & $15.7( \pm 1.2)$ & $13.0( \pm 0.6)$ \\
\hline & d & c & b & $\mathbf{a}$ & $\mathbf{A}$ & $\mathbf{A}$ \\
\hline Leaf & $31.2( \pm 1.9)$ & $33.8( \pm 2.2)$ & $28.3( \pm 2.2)$ & $26.6( \pm 3.2)$ & & \\
\hline area/diameter & $\mathbf{a}$ & $\mathbf{a}$ & $\mathbf{a}$ & $\mathbf{a}$ & & \\
\hline
\end{tabular}

${ }^{1}$ Statistical differences obtained by ANOVA of linear models including axis category and populations as fixed factor, followed by Tukey's pos-hoc test. 
${ }^{2}$ Statistical differences obtained by ANOVA type III Kenward-Roger of mixed linear models including provenance as fixed factor and individual as random factor. 


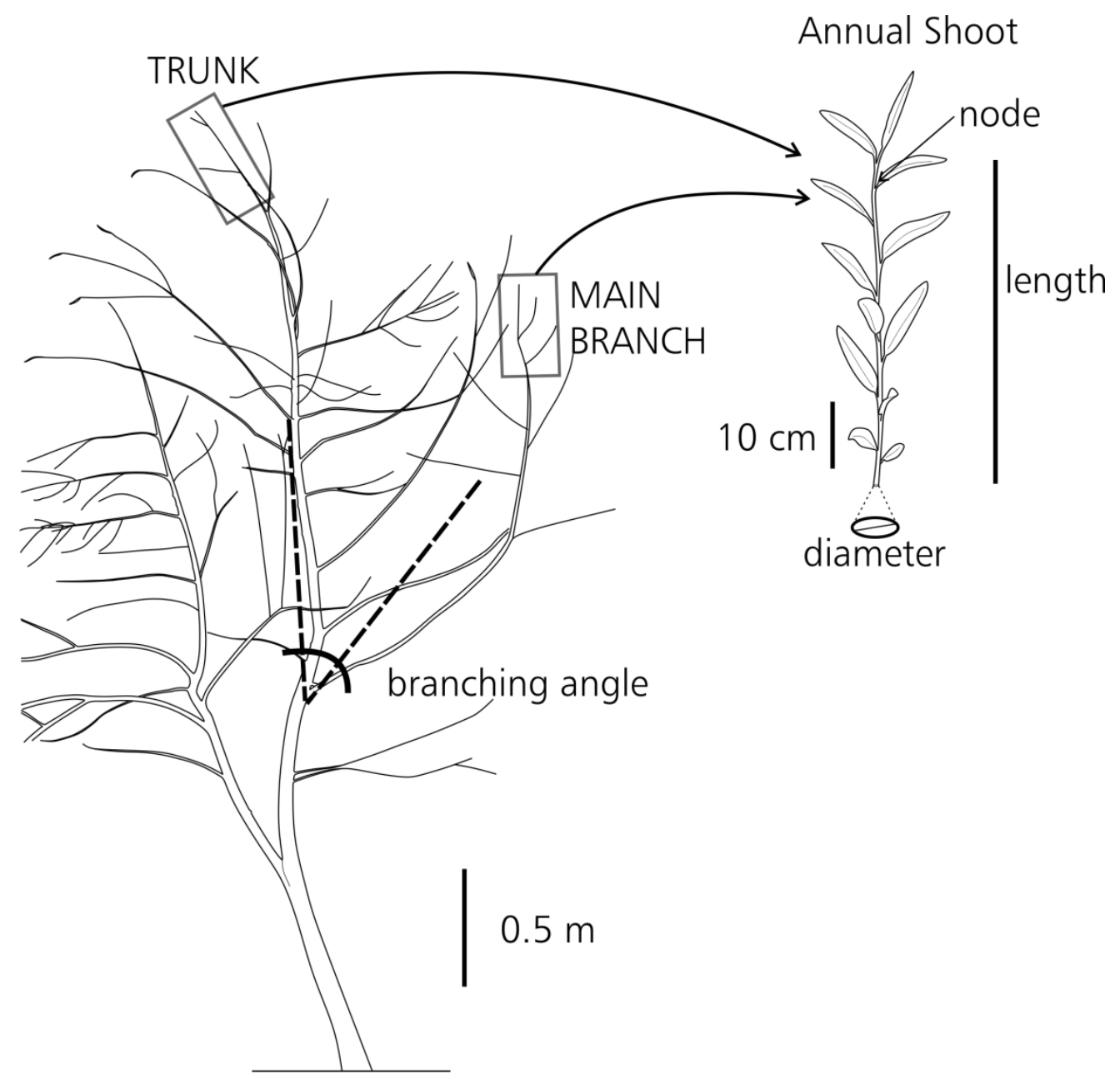

Figure 1. Diagrammatic representation of a Salix humboldtiana tree and main variables measured; at the axis level, the branching angle of the main branch, and at the annual-shoot level, the number of nodes, the length and the basal diameter.

$182 \times 177 \mathrm{~mm}(300 \times 300 \mathrm{DPI})$ 

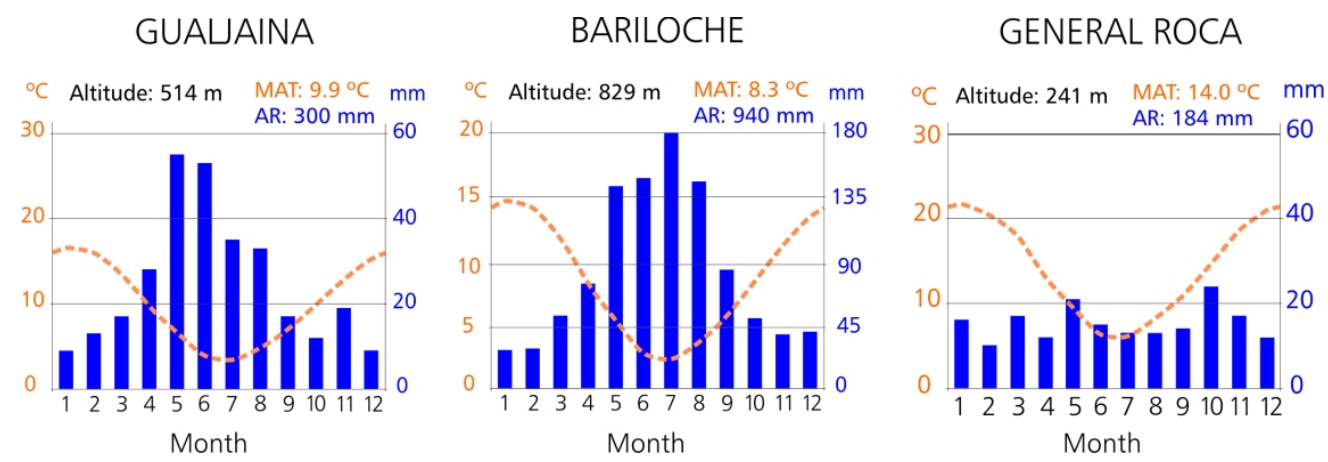

Figure 2. Climographs for localities close to the S. humboldtiana populations at Chubut river (Gualjaina; $42^{\circ} 43^{\prime 2} 27^{\prime \prime} \mathrm{S} 70^{\circ} 32^{\prime 2} 22^{\prime \prime} \mathrm{W}$ ) and at Negro river (General Roca; 39002'01" S 67035'19" W) populations, and

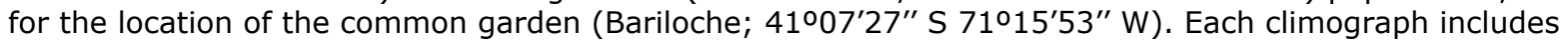
altitude, mean annual temperature (MAT) and annual rainfall (AR). Data from http://en.climate-data.org

$204 \times 68 \mathrm{~mm}(300 \times 300 \mathrm{DPI})$ 


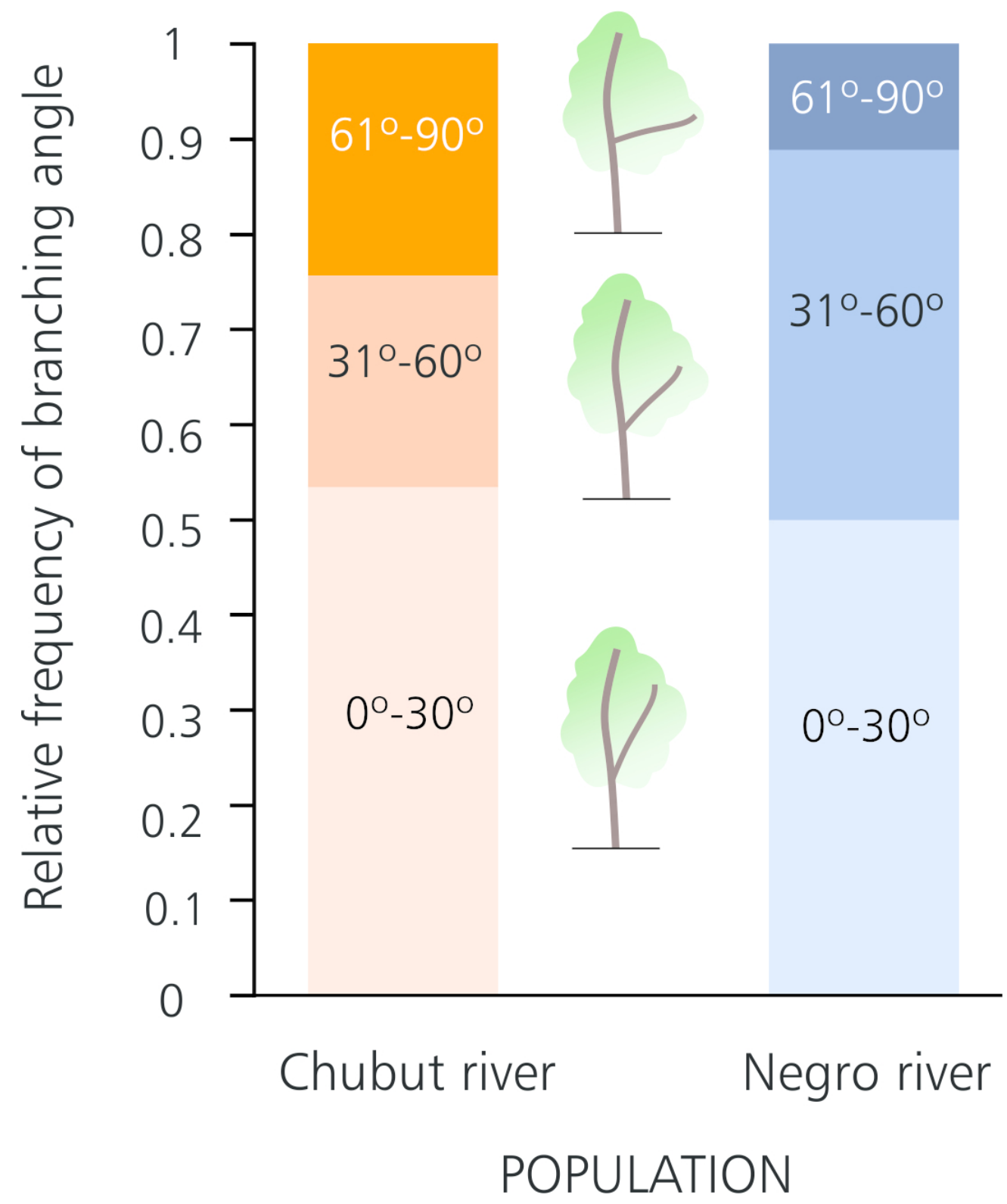

Figure 3. Relative frequencies of branching-angle categories at Chubut river and Negro river populations. $91 \times 110 \mathrm{~mm}(300 \times 300 \mathrm{DPI})$ 

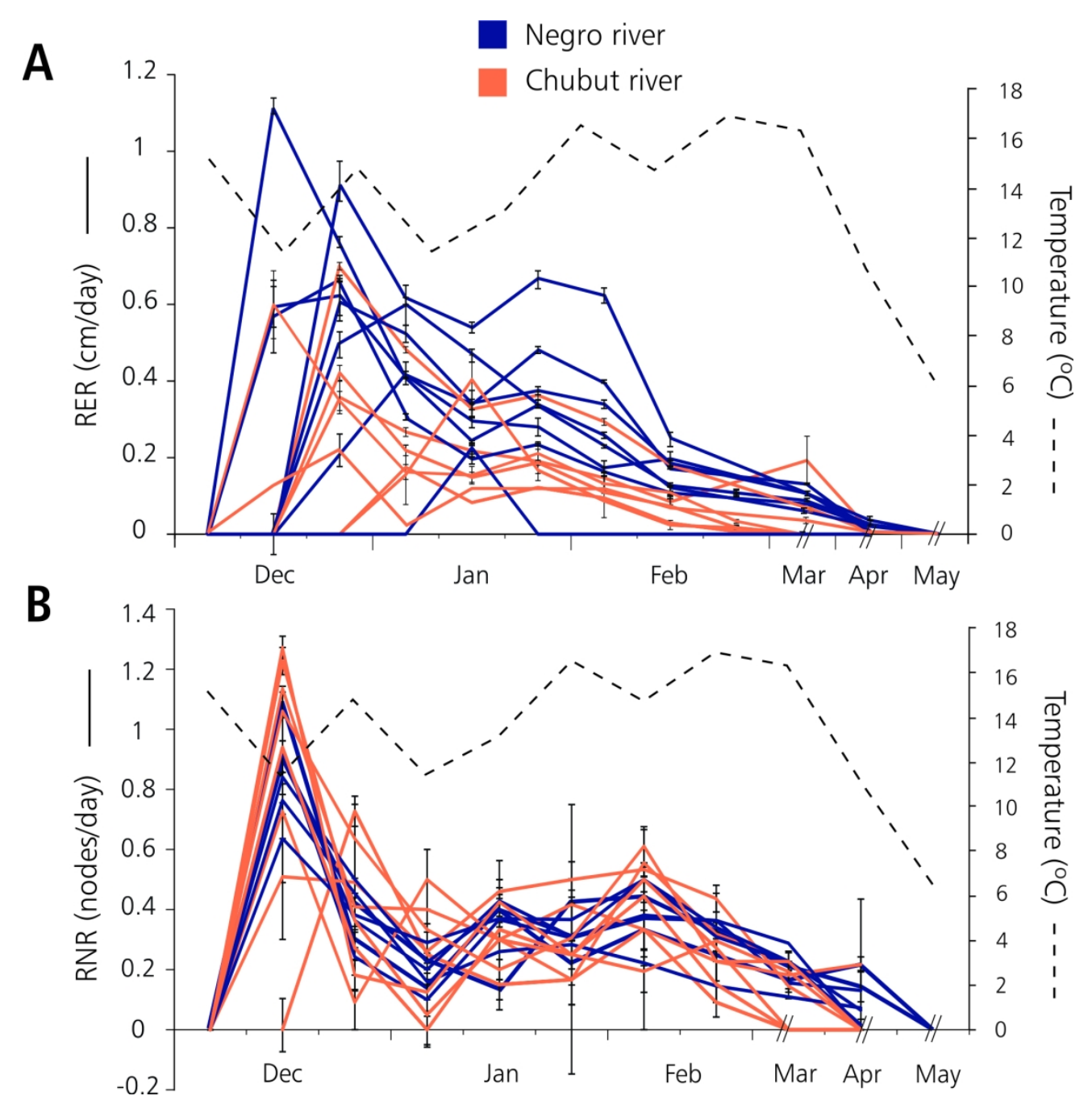

Figure 4. (A) Relative extension rate (RER; $\mathrm{cm} /$ day) as a function of time (solid lines) and mean daily temperature ( ${ }^{\circ} \mathrm{C}$; dotted line). (B) Relative node-production rate (RNR; nodes/day) as a function of time (solid lines) and mean daily temperature ( ${ }^{\circ} \mathrm{C}$; dotted line). Error bars: $\pm 1 \mathrm{SE}$.

$$
173 \times 177 \mathrm{~mm}(300 \times 300 \mathrm{DPI})
$$




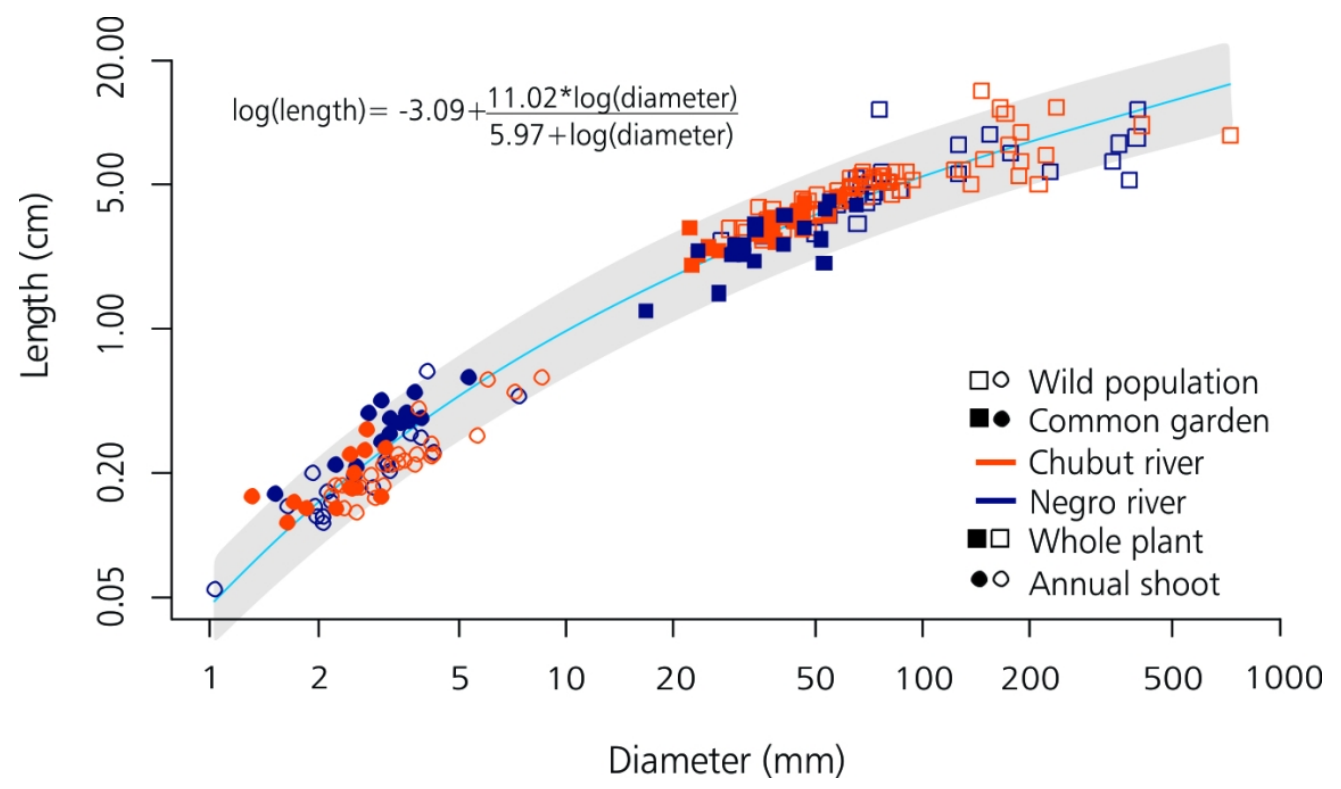

Figure 5. Relationship between stem length and diameter (log-log scale) at annual shoot (circles) and whole plant (squares) levels, for wild-population (empty symbols) and common-garden trees (solid symbols), and for two populations (Chubut river and Negro river). The gray area represents the $95 \%$ confidence interval for the fitted line (inset equation).

$111 \times 65 \mathrm{~mm}(300 \times 300$ DPI $)$ 